\title{
Increasing Vigor, Nitrogen, and Phosphat Content of Oil Palm in Pre Nursery by Seed Coating and Enrichment Trichoderma asperellum, Enterobacter sacchari, and Arbuskular Mycorrhiza Fungi (AMF)
}

\author{
Esty Puri Utami ${ }^{1}$, Eny Widajati ${ }^{2}$, Endah Retno Palupi ${ }^{3}$, Nurita Toruan-Mathius ${ }^{4}$ \\ \{estypuriutami@uinsgd.ac.id ${ }^{1}$, eny.ipb@gmail.com ${ }^{2}$, erpalupi@yahoo.co.id ${ }^{3}$, iwmathius@yahoo.com $\left.{ }^{4}\right\}$ \\ Faculty of Science and Technology, UIN Sunan Gunung Djati Bandung ${ }^{1}$, IPB University ${ }^{2-3}$, PT SMART Tbk ${ }^{4}$
}

\begin{abstract}
Seed coating and enrichment have a central objective to improve seed performance. The aim of this study is to enhance seed vigor, nitrogen and phosphate content in shoot and rhizosphere by seed coating and enrichment in pre nursery. Treatments were controls, negative controls, coated and uncoated seed with enrichment of $E$. sacchari, coated and uncoated seed with enrichment of AMF, coated and uncoated seed with enrichment of $T$. asperellum, coated and uncoated seed with enrichment of consortium T. asperellum $+E$. sacchari, coated and uncoated seed with enrichment of consortium AMF $+E$. sacchari, coated and uncoated seed with enrichment of consortium T. asperellum $+\mathrm{AMF}$, coated and uncoated seed with enrichment of consortium T. asperellum + AMF + E. sacchari. Observation were conduct towards seed germination, rate of germination, nitrogen and phosphate content in rhizosphere and shoot. Generally, coating seed with CMC 1,5\% was not given significantly differences result for all treatment. Enrichment with consortium microbes promising to increase vigor, and nutrient content of seedling in pre nursery.
\end{abstract}

Keywords: Seed enhancement, technology, PGPR, phosphate, consortium

\section{Introduction}

Seed coating is the treatment of coating the seeds with a thin layer without changing the shape of the seeds in order to improve seed appearance, improve storage capacity, reduce the risk of the disease from the environment around the seed, and can be used as a carrier of additives, such as antioxidants, anti-microbes, growth regulators [1]. Coating materials that can be used include arabic gum, sodium alginate, CMC, gypsum, and other non-toxic ingredients. The combination of enrichment and coating of seeds has been widely used, for example in rice, Coating with using $3 \%$ alginate $+1 \%$ peat $+P$. diminuta A 6 was able to increase the percentage of pithy and empty grain weight per panicle and the percentage of pithy and hollow grain per panicle [2]. Enrichment and coating of seeds using talk + CMC $1.5 \%+1 \%$ glycerol + probiotic bacteria can also be used to maintain the viability of rice seeds infected with $X$. oryzae pv. oryzae for 6 weeks in storage [3].

Endophytic microbes have the potential to be added through seed enrichment. The microbes that can be utilized are AMF and Trichoderma sp. The use of these two microbes has become a standard operational procedure (SOP) in the preparation of oil palm seedlings, especially if the seeds will be planted on land infected with Ganoderma boninense. The dose of microbial use continues to increase along with the stage of seedling development. The dose of AMF was given is $5 \mathrm{~g}$ per seed, increasing to $50 \mathrm{~g}$ per tree in the field [4]. A hectare land of oil palm has around 136 plants, it needs about $6.800 \mathrm{~g} / \mathrm{ha}$. Problems arise because of AMF carried along with the carrier material, zeolite, so that the transport of AMF to the land will high. Application of AMF through enrichment and coating of seeds hoped can be a solution for transporting these microbes to the land effectively and efficiently.

The application of T. asperellum in oil palm plants mainly aims to control Ganoderma boninense. [5] applied T. asperellum by soaking the seed for 1 hour on liquid suspension of $T$. asperellum followed by $1.5 \% \mathrm{CMC}$ coating, effective to increase the growth of oil palm 
seedlings in the pre-nursery and can maintain T. asperellum on roots until 12 weeks after sowing. In addition, enrichment techniques with soaking technique is more effective to inserting microbes into seeds because microbes directly contact with seeds. Another microbe that is widely used in seed enrichment is Enterobacter sacchari. This bacterium is an endophyt bacteria in sugarcane which has the ability to fixation nitrogen from the air [6].

Enrichment and coating are generally applied to horticulture seeds, while application to oil palm seeds has not been done much because the structure of seed is more susceptible to mechanical damage than other seeds. The enrichment and coating of oil palm seed has been investigated by [5] using T. asperellum and [7] using Burkholderia sp. use various types of coating materials. The application of consortium AMF, T. asperellum, and E. sacchari followed by $\mathrm{CMC} 1.5 \%$ coating is expected to increase the vigor of oil palm seedlings at the pre-nursery stage.

\section{Method}

\subsection{Seed}

The seed was DxP Tenera aged 21 days from PT Dami Mas Sejahtera, Riau. Length of plumule 1-3 $\mathrm{cm}$ and radicle 2-3 $\mathrm{cm}$. Microbes were Trichoderma asperellum, AMF genus Accaulaspora, and Enterobacter sacchari from collection of PT SMART Tbk.

\subsection{Increased seed vigor through seed enrichment with microbes and coating}

This experiment used a randomized block design with two treatments, i.e. enrichment with microbes and $1.5 \% \mathrm{CMC}$ coating. The enrichment process was carried out according to the Jawak method (2016). One repetition of the treatment consisted of 30 seed. The volume of distilled water to soak 90 seed was 1,5 L. The dose of AMF used was $5 \mathrm{~g}$ of inoculum for one seed ( $5 \mathrm{~g}$ of inoculum containing 132 spores). The $E$. sacchari and T. asperellum inoculums used were pellets with a density of $10^{9}$ (E. sacchari) and $10^{7} \mathrm{cfu} / \mathrm{mL}$ (T. asperellum). Treatment consisted of controls (without microbes and without coating), negative controls (without microbes and with 1.5\% CMC coating), coated and uncoated seed with enrichment $E$. sacchari, coated and uncoated seed with enrichment of AMF, coated and uncoated seed with enrichment of $T$. asperellum, coated and uncoated seed with enrichment of consortium $T$. asperellum + E. sacchari, coated and uncoated seed with enrichment of consortium $\mathrm{AMF}+E$. sacchari, coated and uncoated seed with enrichment of consortium T. asperellum + AMF, coated and uncoated seed with enrichment of consortium T. asperellum $+\mathrm{AMF}+$ E. sacchari. Microbial culture for single microbial enrichment was made by dissolving each microbial inoculum into $1.5 \mathrm{~L}$ of distilled water. The microbial consortium culture was made by dissolving two or three types of microbial inoculum according to the treatment into $1.5 \mathrm{~L}$ of the same distilled water. After enrichment, seeds were coated with $1.5 \% \mathrm{CMC}$ using seed coating machine type AGH 2016, with a speed of $25 \mathrm{rpm}$ for \pm 3 minutes. CMC is sprayed manually on seeds. After perfect coating the seeds were dried for \pm 30 minutes, then planted in a $21 \times 15 \mathrm{~cm}$ polybag containing top soil media. The polybag was then placed on the bed.

\subsection{Observation}

\section{Plant growth parameters}

Seed germination : percentage of seed that grow into normal seedling on $20^{\text {th }}$ and $30^{\text {th }}$ days after planting (DAP). Rate of germination : the number of seeds that have grown normally every day until $40^{\text {th }}$ DAP. 
Analysis of levels of nitrogen $(\mathrm{N})$ and phosphate $(\mathrm{P})$ in soil

Analysis of soil $\mathrm{N}$ and $\mathrm{P}$ was carried out before and after the planting medium was planted with seeds (3 months after sowing (MAS)). Analysis was carried out from three soil samples taken randomly in every replication, then samples of test soil in PT SMART Tbk analytical laboratory. The analysis method for total $\mathrm{N}$ is + FIA. The total P analysis method is ICP-OES and available $\mathrm{P}$ is Bray.

Analysis of $\mathrm{N}$ and $\mathrm{P}$ levels in leaf tissue

Analysis of $\mathrm{N}$ and $\mathrm{P}$ leaf tissue was used to determine nutrient status of nitrogen and phosphorus in plants. The material used is leaves. The leaves were cleaned then dried in an oven at $70^{\circ} \mathrm{C}$ for 24 hours (Huda 2015). After that, the leaves were crushed using a blender and sifted with a $0.5 \mathrm{~mm}$ sieve. The leaves that passed the filter were then tested at the PT SMART Tbk analytical laboratory. The analytical method used is dry ashing + ICP-OES, N (colorimetry).

\subsection{Data calculation and statistical analysis}

The data obtained from the experiment was calculated with analysis of variance (ANOVA) to determine the statistical significance of measurement parameters among treatments. If the result from ANOVA showed significant differences $(\mathrm{P}<0.05)$, Duncan's multiple range test (DMRT) was continually used to compare each treatment. The analysis was done using STAR statistical analysis software.

\section{Result}

\subsection{Seedling Vigor}

Treatments were significantly different to seed germination and rate of germination. Enrichment with consortium microbes $\mathrm{AMF}+E$. sacchari, T. asperellum $+\mathrm{AMF}, T$. asperellum $+\mathrm{AMF}+E$. sacchari in coated seed showed the highest seed germination percentage. As for uncoated seed, consortium microbes T. asperellum + E. sacchari, AMF + E. sacchari, and T. asperellum $+\mathrm{AMF}+E$. sacchari showed seed germination percentage above $90 \%$ (Table 1). Seed germination was calculated based on normal seedling in 20 and 30 days after planting (DAP). Enrichment with consortium microbes for coated or uncoated seed has highest seed germination percentage. Meanwhile, control, enrichment with E. sacchari, AMF, and T. asperellum needed more that 30 days to reach normal seedling above $90 \%$.

Table 1. The Effect of Interaction between enrichment and coating on seedling germination

\begin{tabular}{lcc}
\hline \multirow{2}{*}{ Seed Enrichments } & \multicolumn{2}{c}{ Seed germination (\%) } \\
\cline { 2 - 3 } Control & Coated CMC 1,5\% & Uncoated CMC 1,5\% \\
E. sacchari & $61,1 \mathrm{~dB}$ & $73,3 \mathrm{dA}$ \\
AMF & $52,2 \mathrm{cB}$ & $88,9 \mathrm{cA}$ \\
T. asperellum & $63,3 \mathrm{eA}$ & $45,6 \mathrm{fB}$ \\
T. asperellum + E.sacchari & $87,8 \mathrm{~dB}$ & $60,0 \mathrm{eA}$ \\
AMF + E. sacchari & $95,6 \mathrm{aA}$ & $95,6 \mathrm{abA}$ \\
T. asperellum + AMF & $96,7 \mathrm{aA}$ & $98,9 \mathrm{aA}$ \\
T. asperellum + AMF + E. sacchari & $95,5 \mathrm{aA}$ & $92,2 \mathrm{bcA}$ \\
Note : Means in the same row suffixed with different lowercase letters or in the same column with & $95,6 \mathrm{abA}$ \\
\multicolumn{2}{c}{ different uppercase letters are different at 5\% levels of significance according to DMRT }
\end{tabular}


Seed encrichment with $T$. asperellum $+E$. sacchari showed the highest percentage rate of germination for uncoated seed (Table 2). Generally, coated seeds with CMC 1,5\% were not gave significantly different result with control.

Table 2. The Effect of Interaction between Enrichment and Coating on Rate of Germination

\begin{tabular}{lcc}
\hline \multirow{2}{*}{ Seed Enrichments } & \multicolumn{2}{c}{ Rate of germination (\% etmai $\left.{ }^{1-1}\right)$} \\
\cline { 2 - 3 } & Coated CMC 1,5\% & Uncoated CMC 1,5\% \\
\hline Control & $3,3 \mathrm{abA}$ & $2,8 \mathrm{cB}$ \\
E. sacchari & $3,1 \mathrm{bA}$ & $3,4 \mathrm{bA}$ \\
AMF & $2,3 \mathrm{cA}$ & $1,9 \mathrm{dA}$ \\
T. asperellum & $2,5 \mathrm{cA}$ & $2,4 \mathrm{cdA}$ \\
T. asperellum + E.sacchari & $3,6 \mathrm{abB}$ & $4,3 \mathrm{aA}$ \\
AMF + E. sacchari & $3,6 \mathrm{abA}$ & $3,7 \mathrm{bA}$ \\
T. asperellum + AMF & $3,6 \mathrm{abA}$ & $3,5 \mathrm{bA}$ \\
T. asperellum + AMF + E. sacchari & $3,7 \mathrm{aA}$ & $3,8 \mathrm{abA}$ \\
\hline Note : Means in the same row suffixed with different lowercase letters or in the same column with & \multicolumn{2}{c}{ different uppercase letters are different at 5\% levels of significance according to DMRT }
\end{tabular}

Generally, enrichment seed with consortium microbes were more vigorous than control. It happened because of consortium microbes can help in vigoring seedling and more over to reducing production cost by reducing the use of fertilizer in pre nursery. When two or three organisms are inoculated together, they are known to show better performance over single inoculation of microbes with different functional properties as long as they are compatible. Consortium microbes also useful to enrich microbial diversity in the rhizosphere of crop plants and enhance the interaction of microbes [8].

\subsection{Nitrogen and Phosphat Content in Plant}

Seed coating is application of substance or material to the seed surface, which enhance the seed performance without altering shape on the seed coat which improve germination. Application of microbes in seed coating refers to enhance nutrients in the surrounding of the seed when the seed is planting. Nitrogen content in soil before and after treatment was not significnatly different. Enrichment with $E$. sacchari could not increase nitrogen content. It happens probably because of the treatments directly insert the microbes into the roots. The seed directly use the nitrogen from fixation [9].

Soil which has higest nitrogen content was uncoating seed with AMF enrichment. Coating treatment gave the significant differences of nitrogen content in soil. The nitrogen soil content of coated seeds with enrichment E. sacchari, Mycorrhiza sp. + E. sacchari, and T. asperellum + Mycorrhiza sp. were higher than uncoating seed. Otherwise, uncoated seed with enrichment Mycorrhiza sp., T. asperellum + E. sacchari, and Mycorrhiza sp. + T. asperellum + E. sacchari were higher than coated seed (Table 3 ). 
Table 3. The Efect of Treatments on Nitrogen Soil Content

\begin{tabular}{lcc}
\hline \multirow{2}{*}{ Seed Enrichments } & \multicolumn{2}{c}{ N-soil (\%) } \\
\cline { 2 - 3 } & Coated CMC 1,5\% & Uncoated CMC 1,5\% \\
\hline Before Planting & $0,12 \mathrm{gA}$ & $0,12 \mathrm{eA}$ \\
Control & $0,16 \mathrm{cA}$ & $0,16 \mathrm{aA}$ \\
E. sacchari & $0,14 \mathrm{eB}$ & $0,15 \mathrm{bA}$ \\
AMF & $0,18 \mathrm{aA}$ & $0,16 \mathrm{aB}$ \\
T. asperellum & $0,14 \mathrm{eA}$ & $0,14 \mathrm{cA}$ \\
T. asperellum + E.sacchari & $0.15 \mathrm{dA}$ & $0,13 \mathrm{~dB}$ \\
AMF + E. sacchari & $0,13 \mathrm{fB}$ & $0,14 \mathrm{cA}$ \\
T. asperellum + AMF & $0,12 \mathrm{hB}$ & $0,16 \mathrm{aA}$ \\
T. asperellum + AMF + E. sacchari & $0,17 \mathrm{bA}$ & $0,16 \mathrm{aB}$ \\
\hline
\end{tabular}

Note : Means in the same row suffixed with different lowercase letters or in the same column with different uppercase letters are different at $5 \%$ levels of significance according to DMRT

Total phosphorus in soil was not influenced by the interaction between seed coating and enrichment. Coating treatments decreased total phosphorus in soil. Enrichment treatments were not give significantly differences with control (Table 4).

Table 4. The Effect of Treatments on Total Phosphorus Soil Content

\begin{tabular}{lccc}
\hline \multirow{2}{*}{ Seed Enrichments } & \multicolumn{3}{c}{ Total Phosphorus (ppm) } \\
\cline { 2 - 4 } & Coated CMC $1,5 \%$ & Uncoated CMC 1,5\% & Means \\
\hline Before Planting & 2925 & 2925 & $2925 \mathrm{~d}$ \\
Control & 4450 & 4761 & $4605 \mathrm{ab}$ \\
E. sacchari & 4798 & 5330 & $5064 \mathrm{a}$ \\
AMF & 4315 & 4655 & $4485 \mathrm{~b}$ \\
T. asperellum & 4399 & 4525 & $4462 \mathrm{~b}$ \\
T. asperellum + E.sacchari & 3884 & 4508 & $4196 \mathrm{bc}$ \\
AMF + E. sacchari & 4340 & 4167 & $4254 \mathrm{bc}$ \\
T. asperellum + AMF & 3640 & 4196 & $3918 \mathrm{c}$ \\
T. asperellum + AMF + E. sacchari & 4149 & 5126 & $4638 \mathrm{ab}$ \\
\hline \multicolumn{1}{c}{ Means } & $4100,04 \mathrm{~b}$ & $4465,93 \mathrm{a}$ & \\
\hline
\end{tabular}

Note : Means in the same row suffixed with different lowercase letters or in the same column with different uppercase letters are different at $5 \%$ levels of significance according to DMRT

Uncoated seed with enrichment AMF $+E$. sacchari has highest available phosphat content in soil. As for uncoated seed, seed with enrichment consortium T. asperellum $+\mathrm{AMF}+E$. sacchari and AMF + E. sacchari were highest among all treatments (Table 5).

Table 5. The Effect of Treatments on Available-P Soil Content

\begin{tabular}{lcc}
\hline \multirow{2}{*}{ Seed Enrichments } & \multicolumn{2}{c}{ Available-P $(\mathrm{ppm})$} \\
\cline { 2 - 3 } & Coated CMC 1,5\% & Uncoated CMC 1,5\% \\
\hline Before Planting & $8,39 \mathrm{iA}$ & $8,39 \mathrm{gA}$ \\
Control & $19,50 \mathrm{hA}$ & $24,90 \mathrm{fB}$ \\
E. sacchari & $28,80 \mathrm{dA}$ & $25,90 \mathrm{eB}$ \\
AMF & $27,00 \mathrm{eA}$ & $26,00 \mathrm{eB}$ \\
T. asperellum & $23,80 \mathrm{fB}$ & $31,40 \mathrm{bA}$ \\
T. asperellum + E.sacchari & $22,10 \mathrm{gB}$ & $28,60 \mathrm{cA}$ \\
AMF + E. sacchari & $36,10 \mathrm{aA}$ & $34,30 \mathrm{aB}$ \\
T. asperellum + AMF & $30,40 \mathrm{cA}$ & $27,90 \mathrm{~dB}$ \\
T. asperellum + AMF + E. sacchari & $34,10 \mathrm{bA}$ & $34,50 \mathrm{aA}$ \\
\hline Note : Means in the same row suffixed with different lowercase letters or in the same column with \\
\multicolumn{2}{c}{ different uppercase letters are different at 5\% levels of significance according to DMRT }
\end{tabular}

The highest shoot-N content was coated and uncoated seed with enrichment AMF $(2,65$ $\%$ ) and 2,77 \%), uncoated seed with enrichment E. sacchari (2,63\%) and coated seed with enrichment $T$. asperellum + AMF $+E$. sacchari $(2,72 \%)$ (Tabel 6). Generally, enrichment with 
AMF increase shoot-N content, but it still need more time to make sure that the effect of treatments. Observation until plant in main nursery was needed. [10] reported that AMF could increase phosphat and nitrogen uptake by plant.

Table 6. The Effect of Treatments on Shoot-N Content

\begin{tabular}{lcc}
\hline \multirow{2}{*}{ Seed Enrichments } & \multicolumn{2}{c}{ Shoot-N Content (\%) } \\
\cline { 2 - 3 } & Coated CMC 1,5\% & Uncoated CMC 1,5\% \\
\hline Control & $2,23 \mathrm{bA}$ & $2,06 \mathrm{cdA}$ \\
E. sacchari & $2,14 \mathrm{bcB}$ & $2,63 \mathrm{aA}$ \\
AMF & $2,65 \mathrm{aA}$ & $2,77 \mathrm{aA}$ \\
T. asperellum & $2,21 \mathrm{bA}$ & $2,34 \mathrm{bA}$ \\
T. asperellum + E.sacchari & $2,06 \mathrm{bcA}$ & $2,11 \mathrm{bcdA}$ \\
AMF + E. sacchari & $1,90 \mathrm{cB}$ & $2,19 \mathrm{bcA}$ \\
T. asperellum + AMF & $2,10 \mathrm{bcA}$ & $1,90 \mathrm{dA}$ \\
T. asperellum + AMF + E. sacchari & $2,72 \mathrm{aA}$ & $2,03 \mathrm{cdB}$ \\
\hline Note : Means in the same row suffixed with different lowercase letters or in the same column with &
\end{tabular}

The main purpose of AMF in this research was to increase phosphat content in both of soil and shoot, but it didn't show up. It happens probably because of the lack amount of AMF spores that we use ( $5 \mathrm{~g}$ propaguls contained of 132 spora). Research of [11] reported that the number of spores that effectively increase plant growth was 500 spores and it takes more than 15 months to see the effect of inoculation AMF-plant.

Research of [12] reported that first stage of AMF growth in infected plant occured more than 3 months. On the end of first month after inoculation, there were appresion and intrardical hypae in root cortex tissue. On the end of second month after inoculation, the formation of hypae intraradical tissue was begun. On the end of third month after innoculation, formation of arbuscula was begun. The presence of the spore has been seen before transplanted to main nursery. Therefor, this research need more evaluated and longer time to see the real effect of consortium microbes and seed coating with $\mathrm{CMC} 1,5 \%$.

\section{Conclusion}

Seed coating was not affected seedling vigor or increasing nutrient content in shoot and soil. Seed enrichment was promising to enhance seedling vigor and nitrogen and phosphat content in shoot and soil.

\section{Acknowledgements}

Authors thanked to PT SMART Tbk who facilitated this research.

\section{Reference}

[1] Pedrini S., Merritt D., Stevens J., Dixon K. : Seed Coating : Science or Marketing Spin ?. Trends in Plant. Vol. 2, pp. 106$116(2017)$

[2] Palupi T, Ilyas S, Machmud M, Widajati E. : Seed Coating with Biological Agent to Increase Plant Growth and Yield of Rice. J. Fitopatol Indones. Vol. 41 No. 3, pp. 174-180 (2013)

[3] Krisnandika A. A. K., Widajati E., Hermawan W., Giyanto : Probiotic Bacteria Pellet to Xanthomonas oryzae pv. oryzae Biocontrol and Rice Seed Viability. Vol 12, No. 1, pp. 27-33 (2016)

[4] Sinarmas Agribusiness and Food: Pedoman Teknis Budidaya Tanaman Kelapa Sawit. Management Committee Agronomy and Research, Indonesia (2007) 
[5] Jawak G., Palupi E. R., Widajati E., Toruan-Mathius N. : Oil Palm Seed Coating with Enriched Trichoderma asperellum (T13) to Suppress Infection of Ganoderma boninense Pat. Jurnal Perbenihan Tanaman Hutan. Vol 6, No. 2, pp. 121-132 (2018)

[6] Zhu B., Zhou Q., Lin L., Hu C., Shen P., Litao Y., An Q., Xie G., Li Y. : Enterobacter sacchari sp. vov., A NitrogenFixing Bacterium Associated With Sugar Cane (Saccharum officinarum L.). International Journal of Systematic and Evolutionary Microbiology. Vol. 63, pp. 2577-2582 (2013)

[7] Saipulloh, Widajati E., Palupi E. R., Toruan-Mathius N. :Effectiveness of Seed Coating to Increase Phosphat Absorption and Growth of Oil Palm Seedling. Jurnal Agronomi Indonesia. Vol 45, No. 1, pp. 86-92 (2017)

[8] Jayashree C and Jagadeesh K. S. : Testing The Effect of The Microbial Consortium on Growth of Vegetable Seedlings in a Farmer's Nursery. International Jurnal of Current Microbiology and Applied Science. Vol. 6, No. 2, pp. 1636-1639 (2017)

[9] James E. K., Olivares F. L. De Olivera A. L. M., dos Reis Jr. F., B., da Silva L. G., Reis V. M. : Further Observations on The Interaction Between Sugar Cane and Glucocetobacter diazotrophicus under Laboratory and Greenhouse Conditions. Experimental Botany. Vol 52, No. 357, pp. $747-760$ (2001)

[10] Bakhtiar Y., Yahya S., Sumaryono W., Sinaga M. S., Budi S. W. : Adaptation of Oil Palm Seedlings Inoculated with Arbuskular Mycorrhizal Fungi and Mycorrhizal Endosymbiotic Bacteria Bacillus subtilis B10 Towards Biotic Stress of Pathogen Ganoderma boninense Pat. Microbiology Indonesia. Vol. 6, No. 4, pp. 157-164 (2012)

[11] Widiastuti H., Sukarno N., Darusman L. K., Goenadi D., H., Smith S., Guhardja E. : Application of Arbuscular Mycorrhizal Fungi Spore as Inoculant to Increase Growth and Nutrient Uptake of Oil Palm Seedling. Menara Perkebunan. Vol. 73, No. 1, pp. 26-34 (2005)

[12] Castaneda T. G., and Romero H. M. : Mycorrhization in Oil Palm (Elaeis guineensis and E. oleifera x E. guineensis) in The Pre Nursery Stage. Agronomia Colombiana. Vol. 31, No, 1, pp. 95-102 (2013) 